\title{
TO THE PERSONALITIES OF THE UKRAINIAN ASTRONOMY: SCIENTIFIC WORK OF KOSTYANTYN SAVCHENKO
}

\author{
Marat Balyshev ${ }^{1}$, Iryna Vavilova ${ }^{2}$ \\ ${ }^{1}$ Central State Scientific and Technical Archives of Ukraine, Kharkiv, Ukraine \\ m.a.balyshev@gmail.com \\ ${ }^{2}$ Main Astronomical Observatory, National Academy of Science, Kyiv, Ukraine \\ irivav@mao.kiev.ua
}

ABSTRACT. The research is devoted to the study of the life and work of the outstanding Ukrainian astronomer-theoretician Kostyantyn Savchenko (1910-1956), who worked in the field of celestial mechanics and dynamic cosmogony at the Kharkiv and Odesa astronomical observatories in 1930-1950 years. As a result of historio-graphic analysis, we found that till now there is no comprehensive study of his scientific biography besides several publications related to certain facts of his life and activity, mostly in the Odesa period, including the reminiscences by Prof V.K.Abalakin. Despite this, the vast majority of aspects of the scientist's life, including his scientific and teaching activity in the Kharkiv period in 1930s, remains unexplored.

The astronomer's scientific work was devoted to the study of the motion and rotation of celestial bodies with variable masses, the exploration of the perturbations of the planets by geometry methods, research of the physical nature of gravity, and the development of cosmogonic theories.

We consistently describe the life and activity of Prof. K.N.Savchenko at the Kharkiv and Odesa astronomical observatories, the scientific and teaching work at the Kharkiv State University, the Kherson State Pedagogical Institute, and the Odesa State University, analyzing the archive documents and his scientific publications.

Keywords: dynamic astronomy, minor planets, celestial mechanics, cosmogony, Kharkiv Astronomical Observatory, Odessa Astronomical Observatory.

АНОТАЦІЯ. У роботі оприлюднено основні віхи життя та творчості видатного українського астронома-теоретика К.М. Савченко, який працював у галузі небесної механіки та динамічної космогонії. На основі архівних документів наведено факти з біографії та проаналізовано основні етапи наукової роботи астронома, присвяченої дослідженню руху та обертання небесних тіл зі змінною масою, збурень планет методами геометрії, фізичної природи тяжіння, розробці космогонічних теорій про походження Сонячної системи.

Документально підтверджена наукова діяльність проф. К.М.Савченка в Харківській та Одеській астрономічних обсерваторіях, викладацька робота в Харківському державному університеті ім. О.М.Горького, Херсонському держаному педагогічному інституті та Одеському державному університеті ім. I.І.Мечникова, проаналізовано його наукові публікації.
Ключові слова: динамічна астрономія, малі планети, небесна механіка, космогонія Сонячної системи, Харківська астрономічна обсерваторія, Одеська астрономічна обсерваторія.

\section{Introduction}

The personality of Professor Kostyantyn Savchenko (27.12.1910 Kherson - 29.11.1956 Odesa), who was a well-known astronomer-theoretician in celestial mechanics and dynamical cosmogony, still remains out of the scientific community. His scientific and lecturing activity is mostly related to the period of 1930s in Kharkiv and in 1944-1956 years in Odesa. The astronomer's scientific work was devoted to the study of the motion and rotation of celestial bodies with variable masses, the exploration of the perturbations of the planets by geometry methods, the calculation and correction of the elements of the orbits of asteroids of the main belt of the Solar system, the research of the physical nature of gravity, and the development of cosmogonic theories about the origin of the Solar system. He was deeply interested in the development of theoretical foundations for substantiating the Kant's cosmogonic hypothesis by the methods of celestial mechanics. Kostyantyn Savchenko had been dealing with this problem all his life, but he never published his manuscript.

We conducted historiographical analysis and testified to the absence of a comprehensive study aimed at reproducing the scientific biography of the astronomer. Some facts from the life and work of Prof. Savchenko can be found in a few biographical and memorial publications, in particular, by Abalakin (1975, 1995), Alexandrov et al. (2002), Zakhozhay (2002), Karetnikov (2005), Sharomova (2007), Vavilova et al. (2012), Bakhchynvanzhy (2015), Omelchuk (2017), Hrushytska (2017), Ivanchenko (2018) as well as in the monograph "200 years of astronomy at Kharkiv University" edited by Shkuratov (2008).

In view of the abovementioned, the aim of our work is to consistently describe the life and activity of Professor K.N. Savchenko (Figure 1) at the Kharkiv and Odesa astronomical observatories, the scientific and teaching work at the Kharkiv State University, the Kherson State Pedagogical Institute, and the Odesa State University analyzing the archive documents and various publications. 


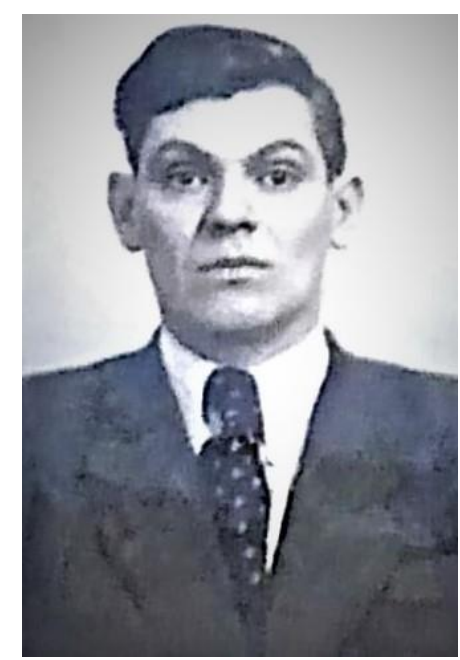

Figure 1: Professor K.N. Savchenko (1910-1956), theoretician in celestial mechanics and dynamic cosmogony

2. The life and scientific activity of Prof. K.N.Savchenko (Kherson and Kharkiv period of life)

Kostyantyn N. Savchenko was born on December 27, 1910 in Kherson in the family of the worker Nikolay I. Savchenko. In 1917, he entered the Kherson city elementary school for seven years; after graduating (1926) he studied at the Construction Department of the Industrial Vocational School.

In 1927, K. Savchenko entered the Faculty of Physics and Mathematics of the Kherson Institute of Public Education named after N.K. Krupskaya (KIPE). Being at the second grade of education, he began also to teach mathematics (at the Courses for Preparation for Higher Education providing by the City Committee of the Komsomol) and physics (at the Cooperative and Veterinary Vocational Schools) as well as to work as an Assistant Professor in physics at the KIPE (Archive of the V.N. Karazin Kharkiv National University (1936-1939), p. 2).

In 1931, after completing a full course of higher education at the KIPE, Savchenko K. became the post-gra-duate student of the Department of Celestial Mechanics of the Kharkiv Astronomical Observatory (KhAO), Kharkiv State University (KhSU). His scientific supervisor was Prof. Aleksey I. Razdolsky (1877-1942), the outstanding astronomertheoretician (Shkuratov, 2008; Balyshev 2020c). He chose the topic of his dissertation under the influence of the wellknown works by Prof. I.V. Meshchersky (1859-1935) on the gravitational dynamics of bodies with variable masses.

In 1934, Savchenko was appointed a Researcher at the $\mathrm{KhAO}$. He also began teaching at KhSU as an Associate Professor of astronomy, in particular, he lectured theoretical astronomy and celestial mechanics at the Astronomical Department of the Faculty of Physics and Mathematics. Since the autumn semester of 1934, Savchenko annually went also to the Kherson and Poltava pedagogical institutes, where he lectured these courses as an Associate Professor (Archive of the Odesa I.I. Mechnikov National University, Personnel File of Savchenko K.N., p. 2).
At the Kharkiv Astronomical Observatory, Savchenko has concentrated his attention and skills on a number of topics and problems. Among them we note as follows: correction of the elements of the orbit of asteroids (89) Julia, (1115) Sabaud, and (1203) Nanna using the method by P. Hansen, as well as (1137) Raisa with taking into account perturbations by the method of mechanical conjugation; study of the series convergence for the decomposition of the perturbation function proposed by M.F. Subbotin (1922); study of the motion of bodies with variable masses; development of cosmogonic theories and other research (for example, Savchenko, 1935). In 1935, Kostyantyn Savchenko defended his dissertation "On the motion of celestial bodies, the mass of which changes over time". The list of his publications to the dissertation is stored in the Archive of the Institute of Astronomy of the V.N. Ka-razin Kharkiv National University.

At that time, Kostyantyn Savchenko focuses his attention to elucidating the cosmogony problems, namely the main ways of scattering the substance of the gas-dust cloud, which did not enter the protoplanetary disks during their formation, filling the gaps between the orbits of these disks and their satellites. And he came to the conclusion that this substance plays a significant role in bringing the system to a stable form, but in the future - it's dissipated by the same system just like "... as exhaust gas by the engine". Savchenko believes that comets, from this point of view, are streams of matter that previously belonged to the gas-dust cloud, and arose due to the perturbed action of protoplanetary disks and they were pushed out of the Solar system. One of his first cosmogonic works, "On the question of the origin of the Solar system" (Savchenko, 1936) received a good response (Barabashov, 1936; Abalakin, 1975).

In the second half of the 1930s, his theoretical activity was aimed to solve problems on perturbed elements of planetary orbits by the geometrical method, theory of epicyclic motion, problem of two bodies, development of field theory by the geometric method (State Archive of the Kharkiv Region, p.10). The Figures 2 and 3 represent a collective of the Kharkiv astronomers (Shkuratov, 2008) with whom Savchenko has collaborated at those times.

During 1938-1939 years, Savchenko lectured on celestial mechanics and mathematical processing of observations for students of the Astronomical Department of the Physics and Mathematics Faculty of KhSU. Altogether with his wife, astronomer L.I. Krysenko (1907-1997), they traveled between Kharkiv and Kherson for a whole year, where they lectured for students at the KhSPI as part-time Associate Professors. On September 1, 1939, the Kharkiv period of life of Prof. Savchenko was over.

Savchenko began to work at the KhSPI, Kherson, as his main place of work, teaching courses in general astronomy and mathematical physics, and his wife in geophysics and physics. But till June, 1940, he continued to work as a Senior Researcher at the Kharkiv Astronomical Observatory. On July 5, 1940 Savchenko K.N. received a degree of Cand. Sci. and diploma of Associate Professor at the Mathematical Analysis Department (Archive of the Odesa I.I. Mechnikov National University, Personnel File of Savchenko K.N.). He followed study on theory of rotational motion of a solid body (Savchenko, 1939). 


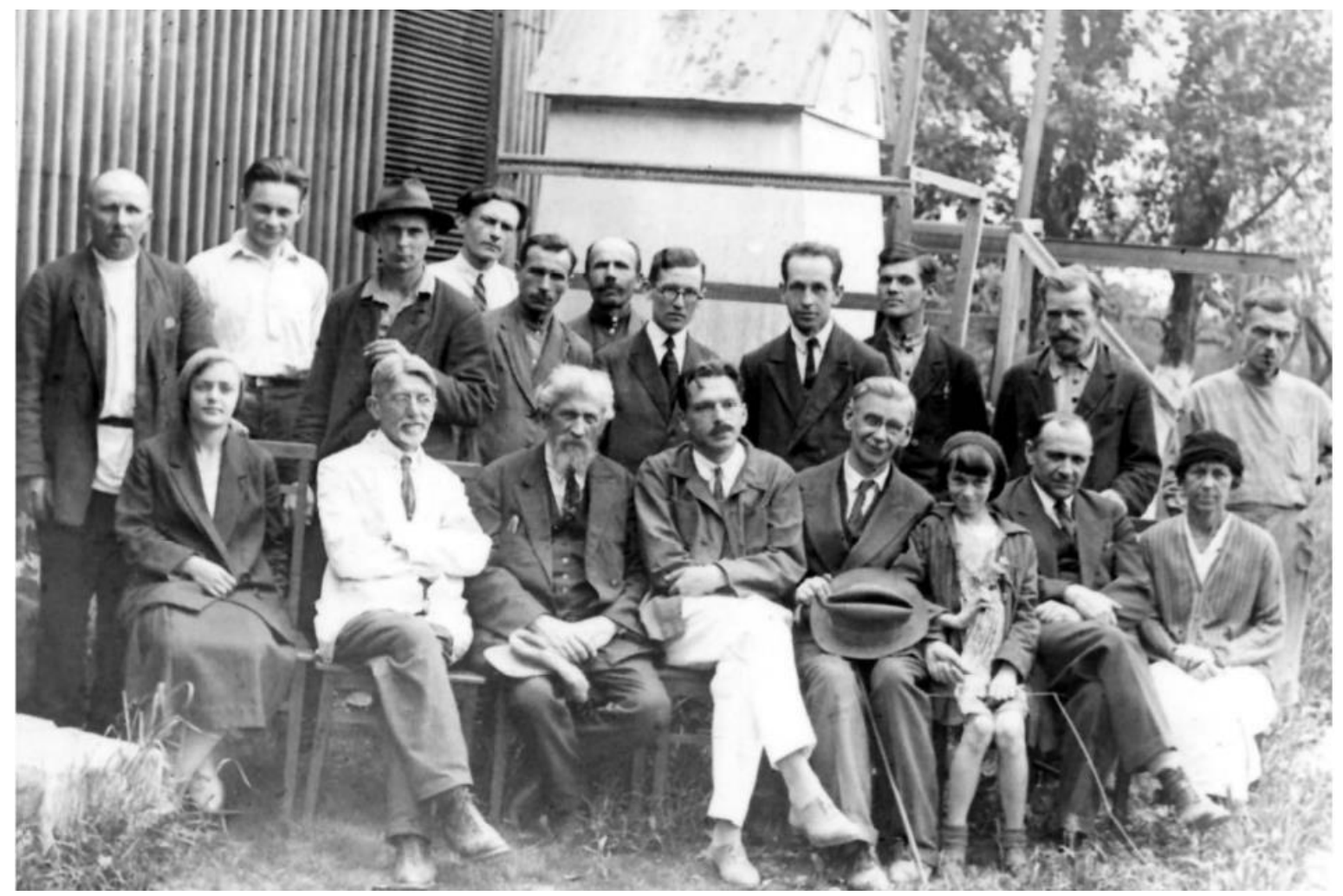

Figure 2: Astronomers of the Kharkiv observatory, early 1930s. From left to right, 1st raw - Krysenko L.I., Razdolsky A.I., Evdokimov N.N., Barabashov N.P., Ostaschenko-Kudryavtsev B.P. and his daughter Zoya, Gerasimovich B.P., Parkhomenko P.G.; 2nd raw - Zinkovsky K.N., Semeykin B.E. (?), Shyngarev L.I., Fadeyev Yu.N., Efimenko E.D., Sawron M.S., Mikhaylov V.A., Savchenko K.N., Inyakhin D.E., Salygin A.S.

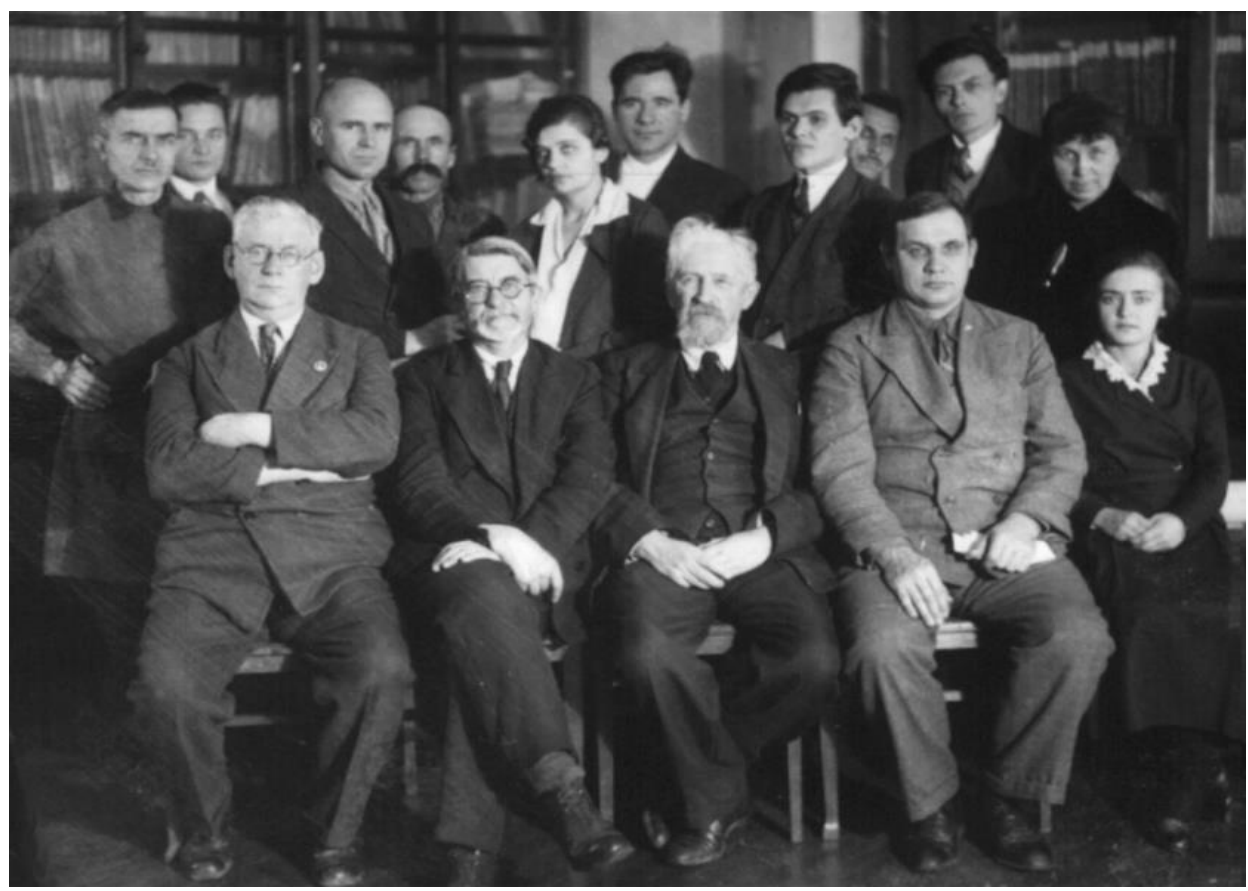

Figure 3: Astronomers of the Kharkiv observatory, late 1930s. From left to right,

1st raw - Ostaschenko-Kudryavtsev B.P., Razdolsky A.I., Evdokimov N.N., Slastenov A.I., Krysenko L.I.; 2nd raw - Salygin A.S., Semeykin B.E. (?), Pluzhnikov V.H., Furdylo V.D., Savchenko K.N., Efimenko E.D., Fadeyev Yu.N., Parkhomenko P.G. 
The war separated the astronomical Savchenko-Krysenko family. In particular, yet in January, 1941, she come back to Kharkiv because the deterioration of her mother's health. The last letter from the husband, Savchenko K.N., she received on July, 1941, from whom she learned that he had been drafted into the Red Army. From the memoirs by K.N. Savchenko about the events of the war period: "In July 1941, a group of teachers from the Kherson institute, who did not serve in the army and had no military training, was sent to organize dig trenches around Mykolaiv. Coming back to Kherson after this work (August 17, 1941), we were detained by the German troops but released after a two-day staying in the camp. During the German occupation of Kherson, I worked as a watchmaker in the artel of the Kustprom. On November 3, 1943, the German command ordered all the men to gather at the P.O.W. camp (Kherson city prison) that meant the general evacuation of all the men to Germany. Trying to avoid it, I fled to Odessa, where I got a job as a watchmaker in one of the private workshops, and worked there until the liberation of the city by the Red Army" (Archive of the Odesa I.I. Mechnikov National University, Personnel File of Savchenko K.N.).

\section{The life and scientific activity of Prof. K.N.Savchenko (Odesa period of life)}

Prof. K.D. Pokrovsky (1868-1944), at that time the Director of the Odesa Astronomical Observatory (OAO) of the Odesa State University (OSU), helped K.N. Sav-chenko to settle in occupied Odesa (watch workshop was placed on the territory of the observatory). At the suggestion of Pokrovsky, Savchenko began working at the OAO since April, 1944, as a Senior Researcher. A statement by K.N. Savchenko, dated April 15, 1944, from his Personnel File: "From 1934 to 1941, I worked as an astronomer at the Kharkiv Astronomical Observatory and Associate Professor at Kharkiv University, lecturing on celestial mechanics and mathematical processing of observations. During this time I also lectured at the Kherson Pedagogical Institute, where taught general astronomy and theoretical mechanics". According to this Personnel File, the fact of his work at KhSU was confirmed by two former lecturers I.G. Wittenzon (1902-1969) and G.M. Mirakyan (1907-1964), who found themselves in post-war Odesa as employees of the re-evacuated Hydrometeorological Institute. It should be noted that these colleagues were not only well acquainted with Konstantin Nikolaevich in teaching at the university (in the 1920s - active members of the Kharkiv Astronomical Club), but also had common scientific interests. For example, Wittenzon also dealt with the problems of dynamics of bodies of variable masses.

In May 1944, Prof. K.D. Pokrovsky was arrested by the NKVD under Art. 54-1 (parricide). Six months after he died in an NKVD prison (Archive of the Office of the Security Service of Ukraine in the Odesa region (1944)).

So, having found himself in Odesa after severe wartime hardships, in April, 1944, Savchenko K.N. began to work at the Odessa Astronomical Observatory as a Senior Researcher, later on as a Head of the Department of Theoretical Astronomy (Karetnikov, 2005). In October 1, 1944, Savchenko was appointed an Associate Professor of Astronomy at the OSU (Archive of the Odesa I.I. Mechnikov
National University, K. M. Savchenko, 1956, p. 34).

In 1945, Savchenko K.N. took part in the Jubilee Astronomical Conference dedicated to the 100th anniversary of the Astronomical Observatory of the Kyiv University. Circumstances of wartime did not prevent well-known astronomers, representatives of many observatories, to go to Kyiv. Scientific reports at the conference from Odesa were made by Prof. V.P. Tsesevich (1907-1983) and K.M. Savchenko. He presented a report "On the nature of gravity", the main postulate of which was a critique of Einstein's General Relativity Theory. In his opinion, for the theory of relativity, gravity remains a hidden property of matter, which it directs to the geometric properties of space. Based on these assumptions, Savchenko considered the gravitational interaction from other positions, focusing on the comparison of certain positions of the wave-mechanical hypothesis of the Gravity Law and the General Relativity. The full text of presentation was later published in the "Vedomosti of the Odessa Astronomical Observatory" (Savchenko, 1949).

In 1946-1947, in order to prepare his doctoral dissertation, K.N. Savchenko continued to develop the theoretical research on the cause of gravity (scientific and theoretical problem of philosophy). He prepared a manuscript of a monograph on "The Nature of Gravity" (not published), which covered in detail the history of the issue. In this work, Savchenko abandoned the critique of A. Einstein's theory, proposing his own wave hypothesis of gravity "Interference of de Broglie waves" and predicted its astronomical consequences. Note that the main positions of the new hypothesis were presented by the author at many scientific events.

In February 1948, Savchenko K.N. defended his doctoral dissertation "The experience of qualitative substantiation of Kant's cosmogony hypothesis"; a year later, in October 1949, by the decision of the Higher Attestation Commission he was approved in the academic title of Doctor of Physical and Mathematical Sciences, and in 1952 was awarded in the title of Professor (Archive of the Odesa I.I. Mechnikov National University of Odesa (1944-1956), p. 15-18).

After Savchenko's defense, two astronomical departments were established at the Faculty of Physics and Mathematics: the Department of Astrophysics (headed by Prof. V.P. Tsesevich, who was the Dean of the Faculty) focused on cooperation with the Department of Physics, and the Department of Astronomy focused on cooperation with the Department of Mathematics. In 1949, Savchenko was approved as a Head of the Department of Astronomy (since 1950 on a permanent basis) and in 1953 he headed the joint Department of Astronomy and Theoretical Mechanics in this university (ibid, p. 31-32). He lectured many different courses, led a student research group, and was a supervisor of post-graduate student's works. Among the courses Savchenko K.N. taught as follows: "Spherical and Theoretical Astronomy", "Celestial Mechanics", "Mathematical Theory of Planetary Figures", "Higher Geodesy", "Theory of Tides", "Dynamic Cosmogony", and "History of Astronomy". Later on he began to give lectures on theoretical mechanics on a part-time basis at the Odessa Higher Maritime Academy (ibid, p. 41-44).

In 1954, K.N. became an Editor-in-Chief of the "Vedomosti of the Astronomical Observatory of Odessa State University" (now - "Odessa Astronomical Publications").

Among the scientific works by K.N. Savchenko during 
the Odesa period of life it is necessary to note the following: "Kepler's problem", "On the motion of the centers of copulation of new stars", "On the origin of the satellites of the planets by gravitational capturing", "On the stability of local dust clusters in nebulae", "On some questions of nonclassical celestial mechanics and cosmogony"; monograph "Essays on celestial mechanics" and the textbook for students "The beginning of the mechanics of the Solar system (Course of Celestial Mechanics)" (Duboshin, 1968).

In 1954, Savchenko K.N. completed a generalized work, the monograph "Kant's cosmogony and the problem of the origin of minor bodies of the Solar system" (Savchenko, 1975), in which he proposed his own cosmogonic concept. But this book as well as the most of Savchenko's scientific works remained in manuscripts and were not published, as the astronomer died suddenly on November 29, 1956, after a heart attack.

One of his post-graduate students, later on an outstanding world-well-known astronomer in field of celestial mechanics, Prof. Viktor K. Abalakin wrote: “... From numerous, rather frank, conversations with K.N. Savchenko, his personality was emerged as the talented, original, and versatile scientist, the intellectual-nugget type of a-self-mademan, who went through arduous and difficult life path in Soviet times" (Abalakin, 1995). The monograph "Kant's cosmogony and the problem of the origin of minor bodies of the Solar system" was issued only in 1975 due to the efforts of Prof. V.K. Abalakin.

\section{Conclusion}

Professor K.M. Savchenko successfully worked in the field of dynamic astronomy and cosmogony, focusing on the problems of non-classical celestial mechanics. He conducted research at the top level of those times at the Kharkiv and Odesa astronomical observatories as well as lectured at the universities in Kharkiv, Odesa, Kherson. The main field of Savchenko's scientific interest was a cosmogony. Investigation of his publications related to the origin of minor bodies of the Solar system requires a deeper analysis and will allow us to understand a worldwide of this outstanding Ukrainian astronomer of the first half of the XX century (Balyshev, 2021).

We assume that the materials of historical and biographical research of the life and work of Prof. Savchenko could be used among others personalities when studying the history of astronomy in Ukraine. Among such papers we note essays about Orlov A.Ya. (Yatskiv et al., 2005a, 2012; Volianskaia et al., 2005), Fedorov E.P. (Korsun', 1989) and Braude S.Ya. (Vavilova et al., 2007), dynasties by Knorre (Pinigin, 2009) and Struve (Krisciunas, 1988; Artemenko et al., 2009), scientists who worked in field of the General Relativity (Yatskiv et al., 2005, p. 194-237; 2017), recent publications dedicated to Tsesevich V.P. (Andronov, 2017; Vavilova, 2017) as well as series of papers about the Kharkiv astronomers as Otto Struve (monograph by Balyshev, 2008; Balyshev, 2007), P. Parkhomenko (Balyshev, 2018a), B. Semeykin (Balyshev, 2018b, 2018c), M. Sawron (Balyshev, 2020a), A. Razdolsky (Balyshev, $2020 b)$ etc. Among the works of a general overview related to the "Astronomers - Ukraine" we note biographical encyclopedia by Kolchinskij et al. (1986) and Vavilova \&
Plachinda (2003), series of books about the Odessa astronomers edited by Karetnikov (1994) (see, also, Korpun \& Tsesevich (1956), Mykolaiv astronomers edited by Pinigin (1998), Kyiv astronomers by Kazantseva \& Kislyuk (2006), Crimean astronomers by Polosukhina (2011), L'viv astronomers edited by Novosyadlyj (2011), and fundamental monograph "200 years of astronomy at Kharkiv University" edited by Shkuratov (2008) where numerous papers are collected about scientific school by Prof. N.P. Barabashov (see, also, Yatskiv \& Vavilova, 2011).

The most of biographies of the Ukrainian astronomers are available at the web-site of the Ukrainian Virtual Observatory: http://ukr-vo.org/personalities/index.php?b\&6 (Vavilova et al., 2014) as well as some of well-known personalities are included into the biographical encyclopedias of astronomers (for example, Lankford, 1996; Krisciunas, 2004; Hockey, 2007, 2013).

\section{References}

Archive of the Institute of Astronomy V. N. Karazin Kharkiv National University (1931-1939). [in Ukrainian].

Archive of the Odessa I.I. Mechnikov National University (1944-1956). Inv. of D.E.T. in 1956. Personnel File by Savchenko K. M., 48 p. [in Russian].

Archive of the Odesa I.I. Mechnikov National University; K. M. Savchenko. For scientific cadres. 1956. No 37. December 5, 4 [in Ukrainian],

Archive of the Office of the Security Service of Ukraine in the Odessa region (1944). Archive-criminal File № 26277-p on Pokrovsky K.D. (1868-1944). Vol. 1. P. 48-320.

Archive of the V.N. Karazin Kharkiv National University (1936-1939). Inv. of D.E.T. in 1933-1941, Case File No. 278, 4 p. [in Ukrainian].

Let's not forget, we remember: employees of Odesa I.I. Mechnikov National University during the Second World War (2015). Eds. A.P. Bakhchyvanzhy, A.S. Lozheshnik. Odesa, 437 p.

Nikolaev Astronomical Observatory. Stellar Way in 175 years: 1821-1996 (1998). Ed. G.I. Pinigin. Nikolaev.

Pages of History of Astronomy in Odessa (1994). Part I, Ed. V. G. Karetnikov. Odessa. [in Russian].

State Archive of the Kharkiv Region (1938). F. r-5875. In. 1. C. 16. P. 10. [in Russian].

The History of the Astronomical Observatory of Ivan Franko National University of L'viv (2011). Ed. B. Novosyadlyj. LNU, L'viv.

The Names of Ukraine in Space (2003). Eds. I. B. Vavilova and V. P. Plachinda. K., VAITE (see, also, Vavilova I.B. (2006): Innovation in Teaching/Learning Astronomy Methods, IAU Special Session, 2.

Abalakin, V. K. (1975): Konstantin Nikolaevich Savchenko. In: The problems of the origin of the bodies of the Solar system, pp. 3-6. M.-L.: AS USSR [in Russian].

Abalakin, V. K. (1995): Professor K. N. Savchenko. In: V.G. Karetnikov (Ed.) Pages of the history of astronomy in Odessa. Part 2, pp. 33-39. Odessa [in Russian].

Alexandrov Yu.V., Dudinov V.N., Zakhozhay V.A. (2002): Astronomical School's Report, 3, 2, 5. DOI: 10.18372/2411-6602.03.2005.

Andronov, I. L. (2017): Odessa Astron. Publ., 30, 252. DOI: $10.18524 / 1810-4215.2017 .30 .118686$ 
Artemenko, T. G., Balyshev, M. A., Vavilova, I. B. (2009): Kinemat. Phys. Celest. Bodies, 25, 3, 153. DOI: 10.3103/S0884591309030040

Balyshev, M. A. (2007): Istoriko-Astronomicheskie Issledovaniya, 32, 138.

Balyshev, M.A. (2008): Otto Ludwigovich Struve, 19871963. Moscow, Nauka.

Balyshev, M. A. (2018a): Science and Science of Science, 1, 114. DOI: 10.15407/sofs2018.01.114.

Balyshev, M. A. (2018b): Kinemat. Phys. Celest. Bodies, 34, 2, 98. DOI: $10.3103 / \mathrm{S} 0884591318020022$

Balyshev, M. A. (2018c): Istoriko-Astronomicheskie Issledovaniya, 40, 127.

Balyshev, M. A. (2020a): Science and Science of Science, 2, 96. DOI: $10.15407 /$ sofs2020.02.096.

Balyshev, M. A. (2020b): Studies in History and Philosophy of Science and Technology, 29, 1, 44. DOI: $10.15421 / 272006$.

Balyshev, M. A. (2020c): Science and Science of Science, 3, 92. DOI: $10.15407 /$ sofs2020.03.092

Balyshev M.A. (2021): Kinemat. Phys. Celest. Bodies, 37, 2 (accepted)

Barabashov, M. P. (1936): Astron. Zh., 13, 282 [in Russian].

Duboshin, G.N. (1968): Celestial Mechanics. Mechanics in the USSR for 50 years. Vol. 1 "General and Applied Mechanics". Moscow, Nauka, 416 p.

Ivanchenko, A. V. (Ed.). (2018): The scientists of the universities of Odessa: a bibliography. Issue 2 Natural Science. Part 4 (1946-2017). Physicists. Astronomers. Odessa, ONSL, 256 p. [in Ukrainian].

Hockey, T., Trimble, V., Williams, Th. R. et al. (2007). The Biographical Encyclopedia of Astronomers, Set of 2 volumes, A-L and M-Z. New York, Springer.

Hockey, T., Trimble, V., Williams, Th. R. et al. (2013): The Biographical Encyclopedia of Astronomers, Set of 2 volumes, A-L and M-Z. New York, Springer.

Hrushytska, I.B. (2017): Odesa Astronomical Observatory in postwar years. Sci. papers of the Historical Faculty of Zaporizhzhya National University, 49, 268. DOI: 10.26661/swfh-2017-49-051 [in Ukrainian].

Karetnikov, V. G. (2005): Savchenko Konstantin Nikolaevich. Astronomer. In: Professors of Odessa (Novorossiysk) University: biographical dictionary. Vol. 4 «R-Ya», pp. 52-53. Odessa: Astroprint [in Ukrainian].

Kazantseva L.V., Kislyuk V. S. (2006): Kyiv Window into Space: the History of Kyiv Astronomical Observatory in the Context of the History of Progress of National and World Science. Kyiv, Nash chas [in Ukrainian].

Kolchinskij, I. G., Korsun', A. A., Rodriges, M.G. (1986): Astronomers. Biographical Handbook. Second supplemented and revised edition. Kiev, Naukova Dumka, 512 pp. [in Russian].

Korpun Ya. Yu. \& Tsesevich, V. P. (1956): Istoriko-Astronomicheskie Issledovaniya, 2, 289.

Korsun', A. A. (1989): Istor.-Astron. Issled., 21, 327.

Krisciunas, K. (2004): Name Index to Sky and Telescope, vol. 1, no. 1 (Nov. 1941) to vol. 108, no. 6 (Dec. 2004).
Lankford, J. (1996): History of Astronomy: An Enciclopedia (Garland Enciclopedias in the History of Science, vol. 1. New York, Garland.

Omelchuk, S.A., Samsakova, I.V. (2017): Tavriysky visnyk osvity, 2, 5 [in Ukrainian].

Pavlenko, Ya. V., Vavilova, I. B., Kostiuk, T. (2006): Astronomy in Ukraine. In: Organizations and Strategies in Astronomy, Vol. 7. Ed. A. Heck. Springer, Dordrecht, the Netherlands, p. 71. DOI: 10.1007/978-1-4020-5301-6_4.

Pinigin, G. (2009): Astron. Nach., 330, 6, 578. DOI: 10.1002/asna.200911220

Polosykhina, N. S. (2011): Crimean Astrophysical Observatory. Foundation, Development, Prosperity. Simferopol, Business-Inform.

Savchenko, K. M. (1935): Bull. of the Astron. Observatory of Kharkiv State University, 3, 2 [in Ukrainian].

Savchenko, K. M. (1936): Ucheni zapysky Kharkiv derzhavnogo universytetu, 6-7, 25.

Savchenko K.M. (1939): Theory of rotational motion of a solid body of variable masses. In: "Scientific notes of the Kherson State Pedagogical Institute".

Savchenko K.N. (1949): Vedomosti of the Odessa Astronomical Observatory.

Savchenko, K. N. (1975): Kant's cosmogony and the problem of origin of minor bodies of the Solar system. Probl. proiskhozhd. tel soln. sist., p. $8-243$.

Sharomova, V. (2007): Savchenko K.M. In: Ukrainian Physicists and Astronomers: textbook. Ternopil, p. 212.

Shkuratov, Y. G. (Ed.). (2008): 200 years of astronomy at Kharkiv University. Kharkiv: Kharkiv V.N. Karazin National University, 632 p. [in Russian].

Subbotin, M. (1922): MNRAS, 82, 383. DOI: $10.1093 / \mathrm{mnras} / 82.6 .383$

Vavilova, I. B.; Konovalenko, A. A.; Megn, A. V. (2007): Astron. Nach., 328, 5, 420 DOI: 10.1002/asna.200710762

Vavilova, I. B., Artemenko, T. G., Pakuliak, L. K. (2012): Kinemat. Phys. Celest. Bodies, 30, 1, 46. DOI: 10.3103/S0884591314010073

Vavilova, I. B. (2017): Odessa Astron. Publ., 30, 256. DOI: 10.18524/1810-4215.2017.30.118718

Volianskaia, M. Yu., Karetnikov, V. G., Mandel, O. E. (2005): Odessa Astron. Publ., 18, 138.

Zakhozhay, V.A. (2002): Astronomical School's Report, 3, 26. DOI: 10.18372/2411-6602.03.2026.

Yatskiv, Ya. S., Korsun', A. A., Vavilova, I. B. (2005a): Kinemat. Fiz. Neb. Tel, 21, 6, 403.

Yatskiv, Ya. S., Alexandrov, A. N., Vavilova, I. B. et al. (2005b). General Relativity theory: tests through time. Kyiv, MAO NAS of Ukraine, 288 p. ISBN 966-02-3728-6

Yatskiv, Ya., Vavilova, I.B. (2011): IAU Symposium, 260, 696. DOI: $10.1017 / \mathrm{S} 1743921311003048$

Yatskiv, Ya. S., Vavilova, I. B., Korsun', A. A. (2012): Odessa Astron. Publ., 25, 74.

Yatskiv, Ya. S., Vavilova, I. B., Romanets, O. A., Savchuk, V.S. (2017): Space Sci. \& Tech., 23, 3, 64. DOI: 10.15407/knit2017.03.064. 